\title{
STRUCTURILE DE COMANDAMENT ALE ARMEI GENIU, DIN ARMATA ROMÂNIEI, ÎN PERIOADA 1941-1946
}

\author{
COMMAND STRUCTURES OF MILITARY ENGINEERING BRANCH, \\ FROM THE ROMANIAN ARMY, IN THE PERIOD 1941-1946
}

\author{
Col.drd. Cristian Gabriel CîRJĂU*
}

\begin{abstract}
Situația din perioada anilor 1941-1946 a fost deosebit de complexă, o perioadă în care armata română a participat la operații militare atât în campania din est, dusă împotriva armatei ruse, cât și în campania din vest, dusă împotriva armatei germane, care ne-a fost aliată o perioadă de timp. Pentru conducerea și coordonarea acțiunilor militare, comandamentele române existente sau constituite în funcție de nevoile curente au cooperat îndeaproape atât cu cele germane, cât și cu cele ruse, începând cu momentul în care am întors armele împotriva germanilor. Pe parcursul ambelor campanii, structurile din cadrul comandamentelor române au fost unele nou înființate, și altele organizate și reorganizate, în funcție de nevoile pe care le-a cerut situația curentă. Printre aceste structuri, existau și cele de geniu, care conduceau și coordonau toate activitățile specifice. În cadrul acestui studiu, mi-am propus să identific organizarea și rolul structurilor de geniu, din cadrul comandamentelor române, în conducerea și coordonarea acțiunilor genistice din perioada 1941-1946, cu scopul de a face ulterior, în cadrul unui alt studiu, o analiză comparativă cu structurile de geniu din armata română existente la această dată.
\end{abstract}

The situation during the years 1941-1946 was particularly complex, a period in which the Romanian Army participated in military operations, both in the Eastern campaign against the Russian Army and in the Western campaign against the German Army, which we were allied to for a while. For the leadership and coordination of military actions, the existing Romanian commands, or those established according to current needs, cooperated closely with both the German and as well as the Russian ones from the moment we turned our weapons against the Germans. During both campaigns, the structures within the Romanian commands were some newly established and others organized and reorganized according to the needs required by the current situation. Among these structures, there are those of military engineering, who led and coordinated all specific activities. In this study I aimed to identify the organization and role of military engineering structures, within the Romanian commands, in leading and coordinating engineering actions during 1941-1946, in order to make later, in another study, a comparative analysis with the military engineering structures of the Romanian Army existing at this date.

Cuvinte-cheie: structuri de comandă-control; arma geniu; pionieri; fortificații; comandanți.

Keywords: command and control structures; engineer branch; pionniers; fortifications; commanders.

Situaţia grea a țării și implicarea tot mai profundă a României în campania militară din răsărit și, ulterior, în cea din apus au avut urmări deosebite în ceea ce privește organizarea atât a armatei, adică a structurilor de comandă și control, cât și a trupelor. În perioada în care armata română a participat la război, pe parcursul celor două campanii, conducerea militară a fost exercitată alternativ și simultan de Marele Cartier General și de Marele Stat Major, în concordanță cu evoluția și cerințele operaționale, cu raporturile de colaborare, cooperare și subordonare față de comandamentele

\footnotetext{
*Statul Major al Apărării

e-mail:cirjau_cristian@yahoo.com
}

germane și sovietice. Diverși factori au determinat reorganizarea, organizarea și, implicit, atribuțiile acestor structuri, în special a serviciilor, secțiilor și birourilor din compunere, pe întreaga durată a participării la cea de-a doua conflagrație mondială ${ }^{1}$. Printre acestea, identificăm și structurile de comandament de geniu, care fac obiectul studiului nostru, dar urmează să facem referire și la alte structuri de comandă de geniu, permanente sau temporare, care au existat în acea perioadă.

Motivul elaborării acestui studiu a fost identificarea structurilor de geniu din cadrul comandamentelor armatei române, în perioada 1941-1946, organizarea acestora, atribuțiile și rolul pe care 1-au jucat în conducerea și coordonarea trupelor de geniu. Pentru identificarea structurilor 
de geniu din cadrul comandamentelor armatei române, am studiat o serie de documente aflate în arhivele militare și, de asemenea, o serie de lucrări generale și speciale.

În cadrul acestui studiu, doresc să fac o analiză detaliată a structurilor de comandament de geniu pe care le-a avut armata romană, ulterior colaționând informațiile cu altele, deja reieșite în urma altor studii efectuate, urmând, în continuare, să fac o analiză comparativă cu structurile de comandament de geniu aflate astăzi atât în organizarea armatei noastre, cât și în organizarea comandamentelor NATO sau în cadrul armatelor naționale ale unor state membre ale NATO. Ulterior, după efectuarea acestei analizei comparative a tuturor structurilor de comandament de geniu, atât românești, cât și străine, voi face propuneri concrete pentru reorganizarea și redimensionarea structurilor de geniu din cadrul comandamentelor armatei române.

\section{Organizarea structurilor de conducere ale armei geniu la începutul anului 1941}

La 1 aprilie 1941, conform ordinei de bătaie ${ }^{2}$ oficiale, organele de conducere ale armei geniu și, de asemenea, celelalte structuri din cadrul armei erau organizate și subordonate astfel: la Ministerul Apărării Naţionale, în cadrul Subsecretariatului de Stat pentru Armata de Uscat, existau ca structuri superioare de conducere, Direcția superioară a geniului și Direcția fortificațiilor. În cadrul Subsecretariatului de Stat al Aerului, identificăm Direcția geniului aeronautic, iar în cadrul Subsecretariatului de Stat al Marinei, Serviciul de geniu și transmisiuni.

Ca structură de forțe, în cadrul armatei de uscat la corpurile de armată și la divizii, existau șase regimente de pionieri, un regiment de pionieri gardă și un batalion de geniu motorizat. În cadrul corpului de munte, erau patru batalioane de pionieri munte, iar în organizarea celor două brigăzi de fortificații, găsim două batalioane de geniu fortificații.

În cadrul trupelor aeriene (Aeronautica), identificăm Regimentul de geniu aeronautic, cu Centrul de instrucție geniu aeronautic.

În cadrul marinei regale, Comandamentul Diviziei de Dunăre are în subordine Regimentul geniu marină.

În coordonarea Direcției superioare a geniului, erau Centrul de instrucție al geniului cu unitățile subordonate, Școala de ofițeri de geniu (activi și în rezervă) cu unitățile subordonate, Arsenalul geniului cu Liceul Militar Industrial, Depozitul central materiale de geniu Mogoșoaia, Depozitul materiale de geniu Iași și Depozitul materiale de geniu Sibiu. Ca trupe, Brigăzile 1, 2, 3 pionieri, organizate pe regimente și batalioane, Brigada de căi ferate, organizată pe regimente și batalioane, și Brigada de transmisiuni, organizată pe regimente.

Conform altor surse ${ }^{3}$,în cadrul trupelor de uscat, figurau, la 1 aprilie 1941, următoarele structuri de geniu: Inspectoratul general al geniului, școlile militare de geniu, centrele de instrucție, arsenalul geniului, batalioanele de geniu și de fortificații și depozitele de materiale de geniu, iar pentru coordonarea și controlul nemijlocit al unităților de geniu, existau comandamentele brigăzilor de pionieri, transmisiuni și de căi ferate, specialități care erau organizate pe regimente și batalioane independente.

Regimentele de pionieri și batalioanele de pionieri de munte din cadrul brigăzilor de pionieri erau subordonate nemijlocit și corpurilor de armată corespunzătoare, respectiv brigăzilor mixte de munte, deci aveau dublă subordonare. Brigăzile de pionieri depindeau nemijlocit de Inspectoratul general al geniului. Mai existau un batalion de geniu moto și două batalioane de pionieri fortificații, recent înființate, ele depinzând de Divizia 1 blindată și, respectiv, de Brigăzile 1 și 2 fortificații. Regimentul de pontonieri se afla în subordinea Brigăzii 1 pionieri.

La aceeași dată, Inspectoratul general al geniului avea în organizare: Statul major, Serviciul columbofil, Secția studii și experimentări, Serviciul intendență, Direcția geniului, care, la rândul ei, avea în compunere: Biroul 1 pionieri, Biroul 2 comunicații, Biroul 3 transmisiuni, Biroul 4 administrație, Registratura.

La Marele Stat Major, funcționa Direcția fortificațiilor ${ }^{4}$.

Toate trupele de geniu aveau la pace sarcini de mobilizare. Ele trebuiau să organizeze, să doteze și să mobilizeze unitățile și subunitățile de geniu (pionieri, transmisiuni, pontonieri, căi ferate) necesare la război marilor unităţi și unităţilor de trupe de uscat. Regimentul de Geniu Aeronautic și unitățile de geniu din cadrul marinei militare (transmisiuni, pionieri, arme sub apă și auto) executau mobilizarea pentru nevoi proprii.

În urma analizei efectuate, reiese faptul că, la începutul anului 1941, structurile de geniu din 
cadrul comandamentelor erau organizate ierarhic, aveau o organizare complexă și contribuiau la conducerea sau coordonarea marilor unități și unităţi de geniu. Atribuțiile lor generale constau în conducerea și evaluarea activităţilor de instruire a trupelor, în dotarea cu tehnică și materiale specifice, în gestionarea munițiilor, a echipamentelor și materialelor de geniu, în elaborarea de studii, proiecte și instrucțiuni de specialitate.

\section{Situația organelor de conducere și a trupelor} în timpul campaniei

În tabelele de mobilizare, ediția 1941, era consemnat modul în care urma să se realizeze sistemul de conducere generală a războiului și a armatelor de operații. Acest sistem cuprindea Marele Stat Major cu direcțiile și secțiile sale, inspectoratele generale ale armelor, comandamentele marilor unități operative și tactice.

În baza documentelor din vremea respectivă, la 1 aprilie 1941 erau stabilite, pentru conducerea trupelor de geniu ${ }^{5}$, următoarele structuri: la Marele Cartier General - Eșalonul I: Comandamentul geniului și Comandamentul transmisiunilor, constituite cu cadre din Inspectoratul general al geniului și Brigada de transmisiuni; la Marele Cartier General - Eșalonul II: Direcția fortificațiilor; la Subsecretariatul de Stat al Armatei de Uscat: Direcția geniului (Inspectoratul general al geniului) și Serviciul transmisiunilor; la Cartierul general de armată: Serviciul de geniu, Serviciul transmisiunilor și Serviciul radio-gonio, iar ca șefi ai serviciilor geniu și transmisiuni, au fost numiţi comandanții brigăzilor de geniu și, respectiv, ai regimentelor de transmisiuni; la Cartierul general de corp de armată: Comandamentul geniului, Serviciul geniului, Comandamentul transmisiunilor și Serviciul transmisiunilor. Comandanți ai geniului și transmisiunilor erau comandanții regimentelor de geniu și, respectiv, ofițeri superiori din brigada și din regimentele de transmisiuni; la Cartierul general al corpului de cavalerie: Serviciul geniului și Serviciul transmisiunilor; la divizia de infanterie (Bg.Mx.M., Bg.Cv. și alte tipuri de brigăzi independente) nu erau prevăzute organe de geniu și transmisiuni, problemele corespunzătoare urmau să fie rezolvate de comandanții batalioanelor (escadroanelor) de pionieri sau transmisiuni, aceștia având rolul de șefi de arme.
Concentrarea comandamentelor geniului și transmisiunilor din cadrul Marelui Cartier GeneralEșalonul I a fost prevăzută pentru 14 iunie $1941^{6}$.

La acea dată, generalul de brigadă Barbu Alinescu era încadrat pe funcția de comandant al geniului, deținând și funcția de subinspector general al geniului, iar colonelul Vasile Diaconu, de la brigada de transmisiuni, deținea funcția de comandant al transmisiunilor.

Comandamentul geniului al armatelor de operații apare ca o necesitate pe timpul desfășurării campaniei pe frontul de est, pentru eliberarea Basarabiei și Bucovinei de Nord de sub ocupaţia sovietică. În această campanie, trupele de geniu au executat numeroase misiuni specifice în beneficiul forțelor luptătoare, dar și al celor de sprijin de luptă.

Pentru conducerea şi coordonarea trupelor care desfăşurau aceste misiuni specifice, la 11 iulie 1941 a fost desemnat de către Marele Cartier General, prin ordinul generalului Antonescu, cu numărul 1911/C, Comandant al geniului, al armatelor de operații, generalul de divizie Grigore Georgescu?

Comandamentul geniului al armatelor de operații avea următoarea organizare: Biroul de studii și proiecte de geniu, Biroul de studii și proiecte de transmisiuni și un secretar-dactilograf.

Comandant al transmisiunilor a fost numit colonelul Nicolae Cojocaru. Șef al Biroului de studii și proiecte de geniu a fost maiorul Gr.N. Popescu, iar șef al Biroului studii și proiecte de transmisiuni - maiorul George Slapciu ${ }^{8}$.

Comandamentul geniului armatelor de operații a functionat pe durata campaniei din anul 1941 până în luna decembrie, când Marele Stat Major îl desființează, urmând ca toate atribuțiile acestuia să fie preluate de către Direcția superioară și Comandamentul geniului.

În luna decembrie a anului 1941, potrivit Deciziei Ministeriale $n r .3000$ cu privire la Organizarea şi funcționarea $M A p N$, structurile de comandament de geniu aveau următoarea structură9: la Subsecretariatul de Stat al Armatei de Uscat, existau Direcția superioară și Comandamentul geniului, având în organizare Secția pregătirii de război, Direcția geniului, Serviciul fortificațiilor, Secția columbofilă, Serviciul administrativ, având în subordine comandamentele şi trupele de geniu care nu intrau în compunerea marilor unitătii (Centrul de instrucție al geniului, Școlile de ofițeri și subofițeri, Liceul Militar Industrial, Batalioanele de paza 
lucrărilor de artă C.F. și M.L.P., Arsenalul geniului, Depozitele materiale de geniu); Direcția domenii și construcții militare cu Serviciul studii și proiecte, Serviciul execuție evidență, Serviciul verificări, recepții, exploatare și Serviciul administrativ; la Subsecretariatul de Stat al Armatei Aerului, în subordinea Direcției Superioare Aeronautică, era Direcția geniu aeronautic cu Secția transmisiuni și pândă, Secția geniu aeronautic, Secția infrastructură, Secția terenuri; la Subsecretariatul de Stat al Marinei, identificăm Serviciul geniu și domenii.

Pe lângă Direcția superioară de armă, „funcționa un Comitet consultativ care dădea avize asupra chestiunilor în legătură cu atribuțiunile direcției respective" $"$.

La 1 aprilie 1942, la conducerea Direcției superioare și Comandamentul geniului a fost numit generalul de divizie Gheorghe Zaharescu, al cărui mandat va fi până în anul 1946. Acesta îndeplinise, la declararea războiului, funcția de șef de stat major al A. 3 române ${ }^{11}$.

În urma acumulării experienței de război, Marele Stat Major, Direcția superioară și Comandamentul geniului au luat o serie de măsuri cu privire la reorganizarea trupelor de geniu, în concordanță cu potențialul economic și militar al țării.

Principalele măsuri au vizat ${ }^{12}$ : adaptarea conducerii, organizării și dislocării trupelor de geniu, amenajarea pentru apărare a teritoriului Basarabiei și Moldovei și înzestrarea trupelor cu noi categorii de tehnică, echipamente și materiale de geniu.

a) Adaptarea conducerii, organizării și dislocării trupelor de geniu ${ }^{13} \mathrm{~s}-\mathrm{a}$ realizat la toate nivelurile ierarhice.

În luna iulie a anului 1943, identificăm, în organizarea armatei, următoarele structuri de conducere ale armei geniu ${ }^{14}$ : la Subsecretariatul de Stat al Armatei de Uscat, Direcția Superioară și Comandamentul Geniului și Direcția Domenii și Construcții Militare; la Subsecretariatul de Stat al Armatei Aerului, în subordinea Direcției Superioare Aeronautică era Direcția Geniu Aeronautic, iar la Subsecretariatul de Stat al Marinei, Serviciul geniu și domenii.

După cum se poate observa, structurile de comandament ale armei geniu, de la nivelul ministerului nu au suferit modificări în perioada decembrie 1941 - iulie 1943, dar în scurt timp, au fost făcute schimbări, cu scopul de a îmbunătăţi conducerea și coordonarea trupelor. ${ }^{15}$

Astfel, în toamna anului 1943 se produc unele schimbări în cadrul Direcției Superioare și Comandamentului Geniului. Statul major își păstrează organizarea din anul 1941, cu cele șase compartimente: Biroul 1 organizare-mobilizare, Biroul 2 informații, cercetare, lucrări, Biroul 3 instrucție, școli, regulamente, Biroul 4 servicii, intendență, serviciul columbofil și serviciul fortificațiilor, pe când Direcția geniului se reorganizează pe șapte compartimente, în loc de patru, respectiv: Biroul 1 pionieri, Biroul 2 comunicații, Biroul 3 transmisiuni, Biroul 4 telefoane (cheltuieli MApN pentru abonamente), Biroul 5 contracte, Biroul 6 studii și experimentări și ajutantură. Astfel, observăm apariția de noi structuri, respectiv Biroul pionieri, care se separă de comunicații, datorită creșterii rolului pionierilor în operații și, de asemenea, Biroul contracte, care se va ocupa cu problemele legate de dotare. ${ }^{16}$

Tot în aceeași perioadă, se înființează Grupul pionierilor de munte, dispus, la pace, în Brașov, care avea ca principale atribuții ,instrucția și mobilizarea la părțile sedentare ale pionierilor de munte" 17 .

O altă structură nou înființată a fost Corpul special de intervenție, comandat de generalul Virgil Stănescu (fost comandant al geniului al A. 4 române, în campania din 1941). Mai târziu, în anul 1944, acesta își va schimba denumirea în Corpul de construcții, iar unitățile sale vor deveni detașamente (batalioane) de constructii.

Corpul de construcții avea 149 de ofițeri, 139 de subofițeri și 3.197 de trupe. Comandamentul corpului avea stat major cu birouri: 1 - organizaremobilizare, 2 - studii-execuție, 3 - instrucție, 4 - servicii și organe de intendență și sanitar. Misiunea corpului de construcții era de a executa, de a echipa și de a completa cu lucrări de fortificații interiorul țării. În varianta inițială, de Corp special de intervenție, îi revenea ca misiune înlăturarea urmărilor bombardamentelor prin: strângerea bombelor neexplodate, dezamorsarea și distrugerea lor, deminări, îndepărtarea dărâmăturilor, refacerea unor construcții, stingerea incendiilor ${ }^{18}$.

O nouă măsură realizată a constat în reorganizarea de pace a regimentelor de pionieri și transmisiuni. 
Conform Decretului-Lege asupra organizării forțelor armate, din luna octombrie a anului $1943^{19}$, în cadrul trupelor Armatei de Uscat apar armele geniu și transmisiuni, ca arme combatante. Geniul cuprindea unități de pionieri, pionieri gardă, pontonieri, căi ferate (hipo sau motorizate), grupate în regimente și batalioane de corp aparte. Transmisiunile cuprind unități de transmisiuni cu fir și făă fir, grupate în regimente și batalioane de corp aparte.

La 14 noiembrie 1943, prin Decizia Ministerială nr. 2067/1943, Comandamentul transmisiunilor, înființat prin Decretul Regal nr. 3818/1942, se subordonează Marelui Stat Major, din punctul de vedere al organizării, mobilizării și instrucției, iar din celelalte puncte de vedere, va depinde de Subsecretariatul de Stat al Armatei de Uscat prin Direcția superioară și Comandamentul geniului ${ }^{20}$.

b) Amenajarea pentru apărarea teritoriului Moldovei și Basarabiei ${ }^{21}$

După victoria de la Stalingrad, trupele sovietice au continuat cu succes operațiile ofensive împotriva germanilor și aliaților acestora, ceea ce a determinat Marele Stat Major român să-și concentreze atenția asupra organizării pentru apărarea țării și, în mod special, a zonei de est.

Un rol deosebit 1-a avut Serviciul fortificații din cadrul Direcției superioare și Comandamentul geniului, care, în perioada ianuarie-august 1943, a condus și a coordonat importante activități, dintre care menționăm:

- reabilitarea lucrărilor de fortificații din zona Moldovei și extinderea acestora prin executarea altor lucrări noi, pe baza concepției proprii;

- executarea lucrărilor de amenajare împotriva desantului aerian (contra parașutiștilor) a raioanelor de dispunere a unor obiective importante: aerodromuri, baterii de artilerie antiaeriană, depozite de muniții, explozive, armament, carburanţi/lubrifianţi, noduri de comunicații, fabrici și întreprinderi industriale cu producție de război, posturi radio ș.a.

c) Inzestrarea trupelor cu noi categorii de tehnică, echipamente și materiale de geniu ${ }^{22}$

La debutul războiului, trupele de geniu erau echipate corespunzător cu unelte și materiale de geniu rudimentare care se produceau la noi în țară. Însă nu aveau în dotare suficiente mașini de geniu, mijloace explozive și de dare a focului, mijloace de cercetare și de detectare a minelor și mijloace de transmisiuni. La sfârșitul anului 1941 și pe parcursul anului 1942, o parte dintre aceste mijloace și materiale vor fi puse la dispoziția trupelor de geniu de către Germania, pe front, în conformitate cu protocoalele stabilite la începerea războiului. $\mathrm{Cu}$ toate acestea, în continuare, trupele de geniu se confruntau cu mari deficite de tehnică, echipamente și materiale de geniu.

În legătură cu dotarea forțelor cu echipamente și materiale, Direcția superioară şi Comandamentul geniului au coordonat activitatea de cercetare pentru realizarea a noi mijloace de geniu și de transmisiuni. De remarcat este invenția telefonului cu acumulator și a telefonului portativ cu lămpi de către locotenentul (r) Marinescu-Stoiceni.

În perioada 1943-1944, Direcția superioară și Comandamentul geniului au intensificat procurarea materialelor și mijloacelor de geniu de la diverse societăți din Germania, Italia, Austria și Cehoslovacia.

În seara zilei de 23 august 1944, la București a avut loc o lovitură de stat, în urma căreia mareșalul Antonescu și alți membri ai guvernului român au fost arestaţi. La scurt timp, regele Mihai I a transmis la radio o proclamaţie, din care reieșea că România trecea de partea aliaţilor, întorcând armele împotriva Germaniei hitleriste. Ca urmare, șeful Marelui Stat Major a emis Ordinul nr. 678563, transmis tuturor forțelor de uscat, aeriene și navale române, prin care se ordona că se ,încetează lupta și orice act de agresiune contra forțelor sovietice" ${ }^{23}$. Aceste evenimente au reprezentat schimbarea regimului politic din țară și trecerea României în sfera de influență a fostei URSS, care a dictat condițiile armistițiului, încheiat la 12 septembrie 1944.

\section{Urmările întrebuințării trupelor de geniu în campania din est}

Pe parcursul perioadei 1941-1944, efectivele trupelor de geniu au crescut în mod constant, an de an. În iunie 1941, trupele de geniu numărau 72.962 de oameni, dintre care 57\% acționau în zona de operații, ajungând ca, în iulie 1944, să atingă un număr de 148.847 de oameni, dintre care $37 \%$ erau angajați în zona de acțiuni militare.

În acțiunile desfășurate pe frontul de est, cât și în operația Iași - Chișinău ${ }^{24}$, arma geniu, la fel ca toate celelalte arme combatante, a avut mari pierderi umane, de ordinul a miilor (morți, dispăruți, prizonieri), care se înscriu în totalul de 624.770 de oameni pierduţi de armatele de operații ${ }^{25}$. 
Tot pe timpul desfășurării campaniei din est, trupele de geniu au avut mari pierderi materiale. Unele unități de geniu au pierdut aproape în întregime tehnica, materialele și echipamentele din dotare.

În urma operației Iași-Chișinău, pierderile de vieți omenești au fost foarte mari, unități și mari unități ale armatei române și-au pierdut aproape în întregime capacitatea de luptă și au încetat să mai existe. Aceeași soartă au avut-o și trupele de geniu, în mod special unitățile de pionieri și de transmisiuni ${ }^{26}$. Din acest considerent, Marele Stat Major, printr-o serie de ordine și instrucțiuni speciale, va restabili o nouă structură a armatei ${ }^{27}$ atât pentru zona de operații, cât și în interior, luându-se în calcul posibilităţile umane și materiale ale României din acea perioadă, și în concordanță cu prevederile Convenției de armistițiu.

În ceea ce privește trupele de geniu, pagubele umane și materiale au fost atât de mari încât nu s-a reuşit refacerea batalioanelor de pionieri divizionare. Din efectivele rămase și cu noile efective de recruți de la părțile sedentare, la divizii s-a reușit doar formarea a câte o companie de pionieri. În schimb, la corpul de armată rămâne câte un batalion de pionieri și unul de transmisiuni. Pentru a se reuși constituirea batalioanelor și companiilor de pionieri, a fost necesar chiar transferul de efective între unități. Reorganizarea armei geniu s-a făcut ,din mers”, într-un timp foarte scurt, termenul pentru încheierea acesteia fiind stabilit pentru jumătatea lunii octombrie $1944 .{ }^{28}$

La 1 noiembrie 1944, în Instrucțiunile speciale nr. 17200 se consemna desființarea Direcției superioare și Comandamentului geniului și reînființarea Inspectoratului general al geniului, care depindea de Subsecretariatul de Stat al Armatei de Uscat ${ }^{29}$.

Organizarea Inspectoratului general al geniului $^{30}$, la 1 decembrie 1944, era următoarea: Direcția materialelor și lucrărilor de geniu, condusă de un director, cu Secția 1 - Lucrări de geniu, având Biroul 1 - Comunicații drumuri, Biroul 2 - C.F., Biroul 3 - Instrucție și Secția 2 - Materiale de geniu, având Biroul 1 - Materiale Pionieri, distrugeri și geniu, Biroul 2 - Studii și experiențe, Biroul 3 - Materiale construcții poduri și C.F., Biroul 4 -Administrativ, Biroul 5 - Materiale de transmisiuni; Direcția pionierilor, condusă de un director, cu două birouri, Biroul 1
- Organizare, Biroul 2 - Instrucție; Statul major, condus de un șef de stat major, având în organizare două birouri și un serviciu, Biroul 1 - Organizare, mobilizarea, adjutatură, Biroul 2 - Instrucție, școli, regulamente, Serviciul materiale; Direcția transmisiuni, condusă de un director, având în organizare cinci birouri, Biroul 1 - Organizare, Biroul 2 - Instrucție, Biroul 3 - Transmisiuni cu fir, Biroul 4 - Transmisiuni radio, Biroul 5 - Dotare; Serviciul intendenței.

În subordinea Inspectoratului general al geniului $\mathrm{erau}^{31}$ : Centrul de instrucție al geniului $\mathrm{cu}$ Regimentul Centrului; Școala ofițeri de geniu; Școala subofițeri de geniu; Brigada 1 Pionieri, organizată pe regimente; Brigada 2 Pionieri, organizată pe regimente și batalioane; Brigada 3 Pionieri, organizată pe regimente și batalioane și având și Grupul Pionieri Munte; Brigada de Căi Ferate, organizată pe regimente și batalioane; Corpul de construcții; Arsenalul Geniului; Depozitul central materiale de geniu; Comandamentul transmisiunilor care avea în subordine: Școala ofițeri de transmisiuni; Școala subofițeri de transmisiuni; regimente și batalioane de transmisiuni.

Regimentele de pionieri și Corpul Vânători Munte aveau dublă subordonare: către comanda Corpurilor de armată și, respectiv, către Corpul de Munte.

Potrivit Deciziei Ministeriale nr. 2580, din 2 decembrie 1944, cu privire la organizarea și funcționarea Ministerului de Război ${ }^{32}$, în subordinea Secretariatului de Stat al Armatei de Uscat, se afla Inspectoratul general al geniului, care se compunea din: Statul major; Serviciile de intendență și sanitar; Direcția geniului; Direcția lucrărilor; Comitetul consultativ al geniului.

Direcția domenii și construcții militare ${ }^{33}$ apare ca o structură separată, la nivelul inspectoratelor de armă și avea în compunere: Serviciul studii și proiecte, Serviciul execuția lucrărilor, evidența cazărmilor, verificări tehnice, Serviciul recepții, exploatare, organizare, mobilizare, personal, registratură și Serviciul administrativ.

\section{Schimbări produse în reorganizarea, dislocarea și structura trupelor de geniu}

Perioada de după 23 august 1944 și anul 1945 va aduce importante transformări pentru armata română, dar și pentru arma geniu, care au constat 
în desființarea sau fuziunea unor unități militare, ca urmare a punerii în aplicare a Convenției de armistiţiu și introducerii aparatului politic în structura armatei.

La 12 septembrie 1944, a fost semnată Convenția de $\operatorname{armistițiu~}^{34}$, la Moscova, de către reprezentanții guvernului român și ai puterilor aliate, prin care s-a cerut reducerea efectivelor armatei române la un număr de 120.000 de militari pentru trupele de uscat, 5.000 pentru apărarea antiaeriană, 8.000 pentru aviație, 5.000 pentru marină. Aceste cerințe au fost prevăzute și în Tratatul de pace dintre România și puterile aliate, semnat la 10 februarie 1947, care consimțea statutul de țară învinsă al României, deși marile puteri au apreciat contribuția ei militară și eforturile economico-financiare la scurtarea duratei războiului și înfrângerea Germaniei fasciste.

În acest context, Marele Stat Major a trecut la reorganizarea armatei române, fapt ce s-a extins firesc și asupra trupelor de geniu, acțiunea desfășurându-se pe baza Instrucțiunilor speciale nr. 70200, din 1 noiembrie 1944. ${ }^{35}$

Reorganizarea armei geniu a inclus desființări, înființări, transformări și resubordonări de unități și mari unități.

În toamna anului 1944, au fost desființate o serie de unități de pionieri, căi ferate și toate batalioanele și detașamentele special constituite pentru lucrările de fortificații. Regimentul de pionieri moto s-a contopit $\mathrm{cu}$ Centrul de instrucție al geniului, iar Corpul de construcții și Comandamentul transmisiunilor au trecut în subordinea Inspectoratului general al geniului. ${ }^{36}$

În luna februarie a anului 1945, au fost contopite toate centrele de instrucție și școlile militare de ofițeri și subofițeri de geniu, transmisiuni și guarzi de geniu, luând ființă Școala de ofițeri și subofițeri de geniu. $^{37}$

În perioada martie-septembrie 1945, s-au desființat o serie de unități și mari unităţi de pionieri, pontonieri, poduri râuri, transmisiuni, drumuri și pază căi ferate, geniu al marinei, transmisiuni aero, transmisiuni moto și munte, Comandamentele transmisiunilor și pionierilor, Direcția lucrărilor, Corpul de construcțiii ${ }^{38}$.

$\mathrm{Cu}$ efectivele provenite de la comandamentele și unitățile desființate au fost organizate: Direcția geniului, cu regimentele 1, 2, 5, 6 și 7 pionieri; Direcția transmisiunilor, $\mathrm{cu}$ regimentele 1-5 transmisiuni; 2 batalioane de pontonieri; Brigada de căi ferate, cu regimentele 1-5 căi ferate și pază; Regimentul 1 transmisiuni aero, Regimentul 2 pionieri aero, Batalionul geniu marină, instituții de învățământ de geniu și transmisiuni, precum și Direcția materiale și lucrări de geniu. ${ }^{39}$

În perioada 1945-1946, a continuat reducerea efectivelor militare, deci și ale armei geniu și, de asemenea, a început procesul de democratizare a armatei, proces care a avut implicații deosebite și asupra armei.

În urma Convenţiei de armistiţiu și, ulterior, a Tratatului de pace, efectivele armatei române se reduc drastic. Prin Decretul Lege nr. 128, din 12 februarie 1945, semnat de regele Mihai I, și, ulterior, prin Legea nr. 433, din 12 iunie 1946, promulgată tot de rege, se disponibilizează foarte mulți ofițeri, subofițeri și maiștri militari. O parte dintre aceștia au fost de geniu și căi ferate ${ }^{40}$.

În ceea ce privește structurile de conducere ale armei, în luna septembrie a anului 1946, la conducerea Inspectoratului general al geniului a fost numit, în locul generalului de divizie Gheorghe Zaharescu, generalul de brigadă Grigore Ionescu. Noul inspector al geniului a fost un ofițer de valoare, care participase la ambele campanii în timpul războiului.

În structura inspectoratului, apare, pentru prima oară, onouăstructură,respectiv Serviciuldeeducație, cultură și propagandă. Structura Inspectoratului era următoarea: Statul major, Serviciul de educație, cultură și propagandă, comandantul secund pentru instrucție și comandantul secund pentru înzestrare și lucrări tehnice. Direcția lucrări s-a transformat în serviciul lucrări.

Inspectoratul a păstrat unele unități și mari unități de geniu în subordine nemijlocită, iar pe altele, doar din punctul de vedere al instrucției ${ }^{41}$.

\section{Concluzii}

Încă de la începutul anului 1941, structurile de geniu din cadrul comandamentelor armatei române au avut o organizare complexă, cu atribuții pe mai multe linii, necesare pentru conducerea și coordonarea tuturor activităților întreprinse de trupele de geniu. Ulterior, după mobilizarea structurii de forțe şi după implicarea în acțiunile militare, duse în cadrul campaniei din est, aceste structuri de geniu din cadrul comandamentelor au fost adaptate continuu, în funcție de nevoile curente. 
În această perioadă, centrul de greutate a fost axat pe structurile de comandă de geniu, respectiv Direcția superioară și Comandamentul geniului. În urma acumulării experienței de război, prin intermediul acestor structuri, s-au luat o serie de măsuri cu privire la reorganizarea sau înființarea atât a unor noi structuri de geniu de comandă, cât și a unităților de geniu. Măsurile principale au fost adaptarea conducerii, organizării și dislocării trupelor de geniu, amenajarea pentru apărare a teritoriului Basarabiei și Moldovei și înzestrarea trupelor cu noi categorii de tehnică, echipamente și materiale de geniu.

După 23 august 1944 și până la sfârșitul perioadei supuse analizei, în urma desființării Direcției superioare și a Comandamentuluigeniului, se înfiinţează Inspectoratul general al geniului care va contribui la reorganizarea armei geniu, care a inclus desființări, înființări, transformări și resubordonări de unități și mari unităţi.

Succesele armatei române în ambele campanii la care a participat, ale trupelor de geniu, ca și ale tuturor armelor, au avut la bază factori economici, morali și militari. O importanță deosebită au avut-o conducerea fermă și suplă, exercitată pe toată scara comandamentelor, priceperea deosebită cu care comandamentele române au realizat cooperarea cu comandamentele germane și, ulterior, cu cele sovietice.

Comandanții unităților de geniu române de la toate eșaloanele au avut o pregătire teoretică și multă experienţă în conducerea trupelor. Ei au cunoscut și au aplicat cu competență principiile conducerii și întrebuințării trupelor de geniu în operații și lupte ${ }^{42}$.

S-au remarcat cunoașterea neîntreruptă de către comandanți a situaţiei detaliate a forțelor și mijloacelor de geniu, măsurile luate pentru prevenirea momentelor de criză, cerându-se din vreme întăriri de la eșaloanele superioare sau angajându-se populația locală și organele administrației din zonele de operații.

Un rol important 1 -au avut comandanții geniului armatelor sau corpurilor de armată, care, personal sau prin ajutorii lor, s-au aflat la trupe în momentele și în locurile în care se îndeplineau misiunile cele mai importante și decisive, chiar riscându-și viața.

Arma geniu în al Doilea Război Mondial a avut însemnate pierderi umane și materiale. Pierderile trupelor de geniu se ridică la un număr de mii de militari, respectiv ofițeri, subofițeri și trupă.

\section{NOTE:}

1 Ion Giurcă, Maria Georgescu, Statul Major General Român (1859-1950). Organizare și atribuții funcționale, Editura Militară, București, 2012, p. 229.

2 [Marele Stat-Major al Armatei], Ordinea de bătaie a forțelor armate in timp de pace la 1 aprilie 1941, Tipografia Marelui Stat Major, București, 1941, passim (pp. 10-44).

3 [Arh. M.Ap.N.-M.St.M.], Dosar nr. 475/1. Broșura $n r .26 \mathrm{cu}$ ordinea de bătaie a forțelor armate, apud col. (r.) Petre Zaharia, col. (r) Emanoil Ene, col. (r) Florea Pavlov, Istoria armei geniu din România, vol. II, Editura Militară, București, 1995, pp. 90-92.

4 Ibidem.

5 Ibidem, p. 101.

6 Ibidem, p. 103.

7 Ibidem, p. 120.

8 Ibidem, pp. 120-121.

9 [Ministerul Apărării Naţionale], Organizarea şi funcționarea Ministerului Apărării Naționale, Tipografia MAN, București, 1941, p. II-VII, pp. 24-27, 44, 60 (detalii cu privire la atribuțiile structurilor de comandament de geniu).

10 Ibidem, p. 25.

11 Col. Marian Gargaz, col. Mircea Sclipcea, col. Dorin Cheța, col. Benone Burtan, Arma geniu din Armata României. 150 de ani de jertfe și glorie, Editura Centrului Tehnic-Editorial al Armatei, București, 2009, p. 160; Col. Zaharia Petre și colectiv, op.cit., pp. 155-156.

12 Ibidem, p. 188.

13 Ibidem, pp. 188-190.

14 [Marele Stat Major], Ordinea de bătaie a armatei în timp de pace, la 1 iulie 1943, Tipografia Marelui Stat Major, București, 1943, pp. 4-5.

$15^{* * *}$ Legea asupra administrației forțelor armate,

Serviciul Tipografic, București, 1943.

16 Col. Zaharia Petre și colectiv, op.cit., p. 188.

17 Ibidem.

18 Ibidem, p. 189.

19 [Ministerul de Războiu], Decret-Lege asupra organizării forțelor armate, din 27 octombrie 1943, Serviciul Tipografic, București, 1943 , pp. 23-24.

20 *** Registrul istoric 1859-1945. Istoricul Marelui Stat Major General al Armatei, de la înființare și până astăzi, București, 1945, pp. 75-76.

21 Col. Zaharia Petre și colectiv, op.cit., pp. 190-194.

22 Ibidem, pp. 195-196.

23 Coord. mr. Eftimie Ardeleanu, lt.col. Alexandru Oșca, cc.șt.pr. Dumitru Preda, Istoria Statului Major General. Documente. 1859-1947, Editura Militară, București, 1994, pp. 352-353.

24 Col.dr. Nicolae Ciobanu și colectiv, Curs de istoria artei militare, vol. III, București, 1988, pp. 146-149.

25 Col. Zaharia Petre și colectiv, op.cit., pp. 204-206.

26 Ibidem, p. 226.

27 Ibidem, p. 227; coord. mr. Eftimie Ardeleanu și colectiv, op.cit., pp. 353-356.

28 În Marele Stat Major, Ordinea de bătaie și dislocarea de pace a armatei de uscat la 1 decembrie 1944, Biblioteca SMAp, nr.inv. IV/088/1, passim, apar la Corpurile de armată un regiment pionieri gardă, patru regimente pionieri, la Corpul de munte apare un Grup Pionieri Munte cu trei batalioane pionieri munte. 
29 Ibidem, p. 17; col. Zaharia Petre și colectiv, op.cit., pp. 227.

30 Ibidem, p. 228.

31 [Marele Stat Major], Ordinea de bătaie și dislocarea de pace a armatei de uscat la 1 decembrie 1944, pp. 17-18.

32 [Ministerul de Războiu], Organizarea și funcționarea Ministerului de Războiu (conține detalii cu privire la atributiile structurilor de comandament de geniu), 1944, pp. 35, 41-42, 51-54.

33 Ibidem, pp. 57-58.

34 Col. Zaharia Petre și colectiv, op.cit., pp. 331.

35 Ibidem.

36 [Marele Stat-Major], Ordinea de bătaie și dislocarea de pace a armatei de uscat la 1 decembrie 1944, pp. 17-18.

37 [Marele Stat-Major al Armatei], Ordinea de bătaie și dislocare de pace a forțelor armate 1 martie 1945, Tipografia Marelui Stat-Major, București, 1945, p. 33; col. Zaharia Petre şi colectiv, op.cit., p. 331.

38 Ibidem; [Marele Stat-Major al Armatei], Ordinea de bătaie și dislocare de pace a forțelor armate 1 martie 1945 , passim.

39 Col. Zaharia Petre și colectiv, op.cit., p. 331.

40 Ibidem, p. 343.

41 Ibidem, p. 345.

42 [Școala Superioară de Războiu], Cursul de tactica geniului, Biblioteca SMAp, București, 1945, pp. 5-7.

\section{BIBLIOGRAFIE}

*** Legea asupra administrației forțelor armate, Serviciul Tipografic, București, 1943.

*** Registrul istoric 1859-1945. Istoricul Marelui Stat Major General al Armatei, de la înființare și până astăzi, București, 1945.

[Marele Stat-Major al Armatei], Ordinea de bătaie a forțelor armate în timp de pace la 1 aprilie 1941, Tipografia Marelui Stat Major, București, 1941.

[Marele Stat-Major al Armatei], Ordinea de bătaie a forțelor armate în timp de pace la 1 iulie 1943, Tipografia Marelui Stat-Major, București, 1943.

[Marele Stat-Major], Ordinea de bătaie și dislocarea de pace a armatei de uscat la 1 decembrie 1944, Biblioteca SMAp.
[Ministerul Apărării Naționale], Legea asupra administrației forțelor armate, Serviciul Tipografic, București, 1943.

[Ministerul de Războiu], Decret-Lege asupra organizării forțelor armate, din 27 octombrie 1943, Serviciul Tipografic, București, 1943.

[Ministerul de Războiu], Organizarea și funcționarea Ministerului de Războiu, Serviciul Tipografic, București, 1944.

[Marele Stat-Major al Armatei], Ordinea de bătaie și dislocare de pace a forțelor armate 1 martie 1945, Tipografia Marelui Stat Major, București, 1945.

[Şcoala Superioară de Războiu], Cursul de tactica geniului, Biblioteca SMAp, București, 1945.

[Serviciul Istoric al Armatei], Registrul istoric 1859-1945. Istoricul Marelui Stat Major General al Armatei, de la înfințtare și până astăzi, București.

Coord. mr. Ardeleanu Eftimie, 1t.col. Oșca Alexandru, cc.șt.pr. Preda Dumitru, Istoria Statului Major General. Documente. 1859-1947, Editura Militară, București, 1994.

Col.dr. Ciobanu Nicolae și colectiv, Curs de istoria artei militare, vol. III, București, 1988.

Col. Gargaz Marian, col. Sclipcea Mircea, col. Cheța Dorin, col. Burtan Benone, Arma geniu din Armata României. 150 de ani de jertfe și glorie, Editura Centrului Tehnic-Editorial al Armatei, București, 2009.

Giurcă Ion, Georgescu Maria, Statul Major General român (1859-1950). Organizare și atribuții funcționale, Editura Militară, București, 2012.

Coord. col.dr. Popa Costică, Curs de istoria artei militare, vol. III, Editura Academiei Militare, București, 1988.

Col. (r) Zaharia Petre, col. (r) Ene Emanoil, col. (r) Pavlov Florea, Istoria armei geniu din România, vol. II, Editura Militară, București, 1995. 